\title{
Screening of BCL-2 associated X protein gene polymorphism associated with scrotal hernia in domesticated swine using polymerase chain reaction-restriction fragment length polymorphism
}

\author{
Jessica G. Manalaysay', Nathaniel D. Antonio², Ralph Lorenz R. Apilado², \\ Joseph F. Bambico ${ }^{2}$, and Claro N. Mingala, ${ }^{1,3}$ *
}

\author{
* Corresponding Author: Claro N. Mingala \\ Tel: +63-44-456-0731, Fax: +63-44-456-0730, \\ E-mail: cnmingala@hotmail.com

\footnotetext{
' Philippine Carabao Center, Science City of Munoz, Nueva Ecija 3120, Philippines

${ }^{2}$ College of Science, University of the Philippines Baguio, Baguio2600, Philippines

3 Scientific Career System, National Academy of

Science and Technology, Department of Science and

Technology, Taguig, Metro Manila1631, Philippines
}

Submitted Jan 7, 2016; Revised Mar 21, 2016; Accepted Apr 10, 2016
Objective: This study was conducted to screen scrotal hernia in domesticated swine from selected breeders in the Philippines. This defect is associated with a cytosine to thymine mutation in the BCL-2 associated $\mathrm{X}$ protein $(B A X)$ gene of swine.

Methods: Genetic screening was done by DNA extraction followed by amplification and digestion using polymerase chain reaction-restriction fragment length polymorphism, amplifying the 416 bp region of the $B A X$ gene that was subjected to digestion using the Ear I enzyme. Sequencing was also conducted to validate the results.

Results: Results revealed that out of 538 samples tested, 411 (76.4\%) of the samples were found to be normal whereas the remaining were carriers of the mutation in which 80 (14.9\%) were heterozygous mutants and 47 (8.7\%) were homozygous mutants. Pietrain breed was found to have the highest incidence.

Conclusion: Having a scrotal hernia eliminates the chances of using the boar as a breeder stock because the following generations arising from it would most likely exhibit herniation. It is therefore advised to establish a genetic screening method for Scrotal Hernia in the Philippines to eliminate the negative gene from the herd.

Keywords: $B A X$ Gene, Polymerase Chain Reaction-Restriction Fragment Length Polymorphism (PCR-RFLP), Screening, Scrotal Hernia, Swine

\section{INTRODUCTION}

Swine industry in the Philippines is the second largest contributor to the agricultural sector, coming in next to rice, contributing 12 percent to the country's total value of agricultural production. In 2011, swine population inventory was 12.3 million head, that gave way to the production of approximately 1,940 thousand metric tons of hog live weight in the same year [1]. The swine industry is believed to be one of the most organized and highest adopter of technologies as compared to other local animal industries in the Philippines. However, overall swine farm production efficiency in the country still lags behind other countries due to poor reproductive performance. Tonnage of live weight produced per sow per year was seen to be $500 \mathrm{~kg}$ lower compared to other swine producing countries in 2011. Application of gene markers that are associated to economically important traits offers great potential in improving the breeding selection process. Moreover, gene marker assisted selection can also facilitate genetic improvement in terms of carcass quality, disease resistance and in screening against genetic defects in swine breeding herds.

Scrotal Hernia is one of the most common defects in swine, having a prevalence between 
$0 \%$ to $1.5 \%$ in different breeds [2] with a heritability of 0.2 to 0.6 [3]. Scrotal hernia is strictly found in males and is characterized by the protrusion of internal organs, such as the intestines, to the scrotum. This affects their efficacy in feeding, thus altering their capacity to grow. Moreover, these individuals would require higher feed quality plus additional health care considerations increasing the losses for the breeder. Having this defect eliminates the chances of using the boar as a breeder stock since the following generations arising from it would most likely exhibit herniation. In severe cases, the intestine may experience blockage of blood flow, resulting to a case known as strangulated hernia which can rapidly lead to death.

Two causes have been formulated leading to the formation of hernia in swine. This may be due to the failure of the processus vaginalis $(\mathrm{PV})$ to obliterate after the descent of the testis, or the failure of the internal inguinal ring to close, thus resulting to the contents to exit through the external inguinal ring [4]. Treatment of this defect is very sensitive as it may result to the falling out of the intestines, especially during castration.

Manifestations of hernia may arise during weaning ages. The most prominent expression of this defect is a bulge located near the groin area. Studies show that this defect is influenced by many candidate genes, hence being polygenic, all of which are involved in the process of testicular descent and scrotal development. Several loci have been determined in various studies involving single nucleotide polymorphisms (SNPs) or single nucleotide polymorphisms [5-8]. Several chromosomal regions have also been identified to be significantly contributing to scrotal hernia, particularly, SW1686 and SW2157 on SSC2 and SW0075 on $\operatorname{SSC} 13[9,10]$.

A particular gene associated to the formation of scrotal hernia was of interest in this study, the B-cell lymphoma 2 (BCL2)associated X protein or the BAX and its corresponding SNP [3]. Tanyel [11] illustrated the possible pathway of PV obliteration in their study in 2004 where it was stated that BAX was involved in the initiation of the cascade of programmed cell death, leading to the obliteration of the PV $[10,12]$ Limited studies have been conducted regarding this defect; however, there are a number of candidate genes found to be associated with it. On the contrary, the said gene still requires further studying and testing. Findings of Gatphayak et al. [3] revealed that the BAX gene has a direct association with the Scrotal Hernia defect. The BAX gene is accessible at National Center for Biotechnology Information (NCBI) having a GenBank Accession \# NC_010448.3.

Environmental and genetic factors were also seen as contributing factors to the formation of Scrotal Hernia. However, the influences of these have not been fully established up to present. Studies being recorded as early as 1941 have been concerned about this defect. No restrictions to any breed have been noted, but its development was estimated to be 0.29 for Duroc in 5,711 Duroc-sired male pigs, and 0.34 for both Landrace and Yorkshire-sired in 2,227 Landrace-sired and Yorkshire-sired male pigs, respectively [2]. Some studies indicate the possible mode of inheritance of this defect as incomplete dominance, however, very little proof has been generated to establish its viability. Recommendations suggest the elimination of the boar which produces a litter exhibiting high rate of scrotal herniation. Those which produce litters which show minimal rates of herniation do not necessarily suggest that the boar is a transmitter [13].

A reported frequency of $2 \%$ in the entire population of swine manifested the presence of scrotal hernia in Germany. Thai swine breeders, on the other hand, have seen this as an economic problem with about $1 \%$ of the population in industrial swine farms and $5 \%$ in small-sized farms exhibiting the manifestation of the said defect [3]. However, there have been no prevalence studies conducted in the Philippines about this defect at present.

The polymerase chain reaction- restriction fragment length polymorphism (PCR-RFLP) or cleaved amplified polymorphic sequence (CAPS) is a less expensive method capable of locating genes associated with certain genetic disorders [14]. Mutations such as single nucleotide polymorphism, multiple nucleotide polymorphism, deletion, duplication and combination often cause the formation or elimination of a restriction enzyme recognition site. The method uses this circumstance as an advantage to analyze the DNA.

This study was conducted to screen the mutation in $B A X$ gene associated with scrotal hernia, determine its frequency in a population of domesticated swine and identify incidence in different breeds tested. A further aim was to establish a genetic screening method for Scrotal Hernia in the Philippines.

\section{MATERIALS AND METHODS}

All applicable institutional guidelines for the care and use of animals were followed.

\section{Sample collection}

Five milliliters $(5 \mathrm{~mL})$ of blood were collected from 538 randomly chosen swine (207 Large White, 121 Landrace, 81 Chester White, 28 Duroc, and 98 Pietrain) from selected commercial breeders all over the Philippines. Extracted blood samples were placed in vacutainer tubes containing ethylenediaminetetraacetic acid (EDTA) buffer. These tubes were then stored in a cooler maintaining a temperature of less than $4^{\circ} \mathrm{C}$ prior to transportation to the laboratory for DNA extraction and analysis.

For the Scrotal Hernia positive control, tissue samples from two herniated pigs were obtained through the castration of the affected swine. The samples were, likewise, stored in a cooler prior to its transportation.

\section{DNA extraction}

The DNA from each collected blood sample was extracted using 
the Wizard Blood Extraction Kit (Promega Corp., Madison, WI, USA) following the manufacturer's instructions. Conversely, DNA from the tissue of the herniated swine was extracted using the Qiagen DNAeasy Blood and Tissue Kit (Qiagen Inc., Valencia, CA, USA).

\section{Optimization}

This method was used since it allowed the determination of the optimum annealing temperatures at which the oligonucleotide primers would work best [15]. Annealing temperature and cocktail mix optimization procedures were first done prior to the amplification of the extracted DNA samples. Using gradient PCR, several temperatures were tested $\left(51^{\circ} \mathrm{C}\right.$ to $\left.68^{\circ} \mathrm{C}\right)$ as to determine the most ideal annealing temperature for the amplification of the genes of interest.

\section{Polymerase chain reaction- restriction fragment length polymorphism}

After optimization, DNA samples for Scrotal Hernia were subjected to thermal cycling to amplify the 416-bp region of the $B A X$ gene. A cocktail mixture was prepared with the following components: $2 \mu \mathrm{L}$ of $5 \times$ PCR buffer, $1 \mu \mathrm{L}$ of $25 \mathrm{mM}$ $\mathrm{MgCl}_{2}, 0.5 \mu \mathrm{L}$ each of dNTPs and primers, $0.1 \mu \mathrm{L}$ of Taq polymerase adjusted to a final volume of $10 \mu \mathrm{L}$ using $\mathrm{dH}_{2} \mathrm{O}$.

The samples were amplified under the following conditions: initial incubation for 4 minutes under $94^{\circ} \mathrm{C}$, followed by denaturation at $94^{\circ} \mathrm{C}$ with 35 cycles for $45 \mathrm{~s}$, annealing temperature of $63^{\circ} \mathrm{C}$ for 1 minute, elongation of $45 \mathrm{~s}$ at $72^{\circ} \mathrm{C}$, root elongation of 5 minutes at $72^{\circ} \mathrm{C}$ and holding temperature of $-4^{\circ} \mathrm{C}$. The primers used, synthesized by NEB Inc. (Ipswich, MA, USA), were adapted from the study of Gatphayak et al [3] (Table 1).

To detect the SNPC119T of the BAX gene, RFLP mixture for each sample was prepared containing $1.75 \mu \mathrm{L}$ of high performance liquid chromatographywater, $0.5 \mu \mathrm{L}$ of $10 \times$ Trisacetate-EDTA buffer and $0.25 \mu \mathrm{L}$ of the EarI restriction enzyme, manufactured by NEB Inc. (Ipswich, MA, USA). Two and a half $\mu \mathrm{L}$ of the PCR products were then added to each RFLP mixtures and incubated for 30 minutes at $37^{\circ} \mathrm{C}$. Resulting products were loaded into $3 \%$ agarose gel using $5 \mu \mathrm{L}$ for each sample, and $5 \mu \mathrm{L}$ of the $1 \mathrm{~kb}+$ hyperladder (Invitrogen, Carlsbad, CA, USA). Gel electrophoresis subsequently followed where $3 \%$ agarose gel was utilized as the medium for this procedure. Gel red was used for the visualization of the amplicons under the Proteinsimple UV Gel Documentation System (San Jose, CA, USA). Positive controls of Scrotal Hernia were sent

Table 1. Primers used for amplification of the BAX gene

\begin{tabular}{llc}
\hline Primer name & \multicolumn{1}{c}{ Primer sequence $\left(\mathbf{5}^{\prime} \rightarrow \mathbf{3}^{\prime}\right)$} & PCR products $(\mathrm{bp})$ \\
\hline BAX forward & TCAGTTCATCTAGCAGGGAC & $\sim 416$ \\
BAX reverse & CCATGTACTGTCCAGTTCATC & \\
\hline
\end{tabular}

$B A X, B C L 2$-associated $X$ protein; $P C R$, polymerase chain reaction. to First Base Services in Malaysia for sequencing. Results from DNA sequencing were used to verify the results of the RFLP tests.

\section{RESULTS AND DISCUSSION}

Results presented an optimal temperature of $68^{\circ} \mathrm{C}$ due to the production of clearer bands without smearing as well as the absence of non-specific amplicons in the gel. After optimization, the PCR results revealed successful amplification of the $B A X$ gene having fragment size $416 \mathrm{bp}$.

$B A X$ gene has been studied in several researches, however, most were associated with man and other organisms, with limited investigation of its effects and roles in swine [16]. It has been sufficiently proven that BAX plays the same roles several mammalian groups, which may indicate similar roles for BAX in swine as well. This gene was found to be associated with apoptosis, functioning contrary to the BCL2 which was found to inhibit cellular death. Despite the differences in their effects, the members of the BAX family exhibit similar sequences to that of BCL2. Along with two other pro-apoptotic protein families, the BH3 family and the BCL-2 homologues antagonist/ killer $(B A K)$ family, these work hand in hand in initiating apoptosis wherein BH3-only families act as damage sensors and instigate antagonistic action to that of the anti-apoptotic proteins, and the $B A K$ and $B A X$ families induce cellular death [17]. The $B A X$ gene possesses a hydrophobic carboxyl terminal which targets the mitochondria resulting in a breach in the integrity of mitochondria, allowing the exit of pro-apoptotic proteins such as cytochrome C [18].

\section{Restriction fragment length polymorphism}

The restriction site of the Ear I restriction enzyme is the 5'...CTCTTC...3' region of the amplified segment which cuts it into two segments of approximately $296 \mathrm{bp}$ and $120 \mathrm{bp}$. Failure of the restriction enzyme to recognize this restriction site is attributed to the SNPC119T as stated in the study conducted by Gatphayak et al [3]. Mutations in the restriction site, on the other hand, cause the inability of the restriction enzyme to cut the segment due to the absence of a cutting site. Heterozygous mutants would have a normal strand and a mutated strand. The RFLP assay for heterozygous mutants would result in three fragments consisting of fragments with $416 \mathrm{bp}, 296 \mathrm{bp}$, and $120 \mathrm{bp}$. Homozygous mutants will only have 1 band as they have no Ear I cutting sites.

RFLP results for samples tested for Scrotal Hernia can be seen in Figure 1. Normal samples showed two bands having sizes of $296 \mathrm{bp}$ and $120 \mathrm{bp}$. While lanes that have the presence of the 416 bp, 296 bp, and 120 bp bands indicate carriers. Samples with only the $416 \mathrm{bp}$ band imply that the sample is from a homozygous mutant.

Positive controls were also tested to confirm the ability of 


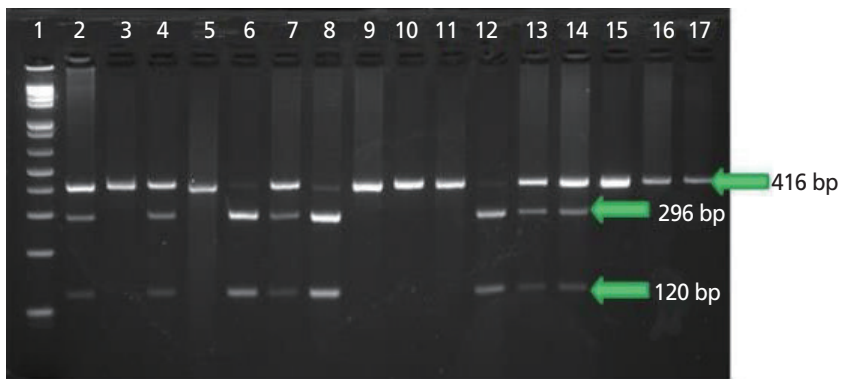

Figure 1. Agarose gel electrophoresis of polymerase chain reaction-restriction fragment length polymorphism test for the BCL2-associated $\mathrm{X}$ protein $(B A X)$ gene. Lane 1 to 100 bp molecular weight ladder. Lanes 2, 4, 13, and 14 are classified as Carrier with 416, 296, and 120 bp; Lanes 3, 5, 9, 10, 11, and 16 are classified as mutant with 416 bp undigested band; Lanes 6, 8, and 12 are normal with 296 and $120 \mathrm{bp}$. Lane 17 is the positive control used.

Ear I to recognize the cutting site, and to serve as the basis of comparison for the bands produced by the other samples. It can be seen that the positive control has only one band which follows and agrees with the results of Gatphayak et al [3] who stated that the mutation would render the said restriction enzyme inactive due to SNPC119T. Furthermore, results for the sequence of the Scrotal Hernia positive controls confirmed the Cytosine to Thymine mutation at the BAX gene (Figure 2). Cleaned sequences obtained from Mega6 software were then aligned, and assembled using Vector NTI Advanced 11.5 software. The assemblage was then inputted into the basic local alignment search tool in NCBI as a confirmatory test to assure that we were able to amplify the correct regions, that is, the $B A X$ gene. Results show that a $99 \%$ to $100 \%$ identity was obtained for the scrotal hernia samples to the Sus scrofa $B A X$ gene (NC_010448.3).

Out of the 538 amplified samples, it was found that only $76.4 \%$ were normal. The remaining $23.6 \%$ has the mutation in $B A X$ gene in which $14.9 \%$ were heterozygous mutants and $8.7 \%$ were homozygous mutants. The results present a high frequency of mutation in the tested population. According to Gatphayak et al [3], while the amplified region is located on the intron of the $B A X$ gene, it can still have a possible effect on the splicing process and these alterations in the splicing can lead to the defect. However, further study of the biological role of the $B A X$ gene is essential to fully understand the mechanism of how the

\begin{tabular}{|c|c|c|c|}
\hline Species/Abbrv & Group lame & 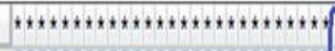 & $7 * * * x * * * * * * x$ \\
\hline 1. gi |347618788:c501063 & & TAGGACCCAAGAGTCCAGGCACCTCI- & efcrecriscic \\
\hline 2. Scrotal hernia 1 - I & & IAGGACCCAAGAGICCAGGCACCICI & crecrescro \\
\hline 3. Scrotal Bernia___: & & IAGGACCCAAGAGTCCAGGCAC & CICCIIICTC \\
\hline 4. Scrotal hernia_2 & & IAGGACCCAAGAGICCAGGCACCI & crectiterc \\
\hline 5. Scrotal Bernia $2 \mathrm{r}$ & & TAGGACCCAAGRGICCAGGCACCI & forccistcic \\
\hline
\end{tabular}

Figure 2. DNA Alignment of the positive controls of scrotal hernia showing the cytosine to thymine mutation at the 119th base of the BCL2-associated $X$ protein $(B A X)$ gene.
Table 2. Incidence of homozygous mutants in $B A X$ gene associated with scrotal hernia among different breeds

\begin{tabular}{lccc}
\hline Breed & $\begin{array}{c}\text { Number of } \\
\text { samples }\end{array}$ & $\begin{array}{c}\text { Homozygous } \\
\text { mutants }\end{array}$ & Incidence (\%) \\
\hline Pietrain & 98 & 26 & 26.5 \\
Landrace & 121 & 3 & 2.48 \\
Large White & 207 & 8 & 3.86 \\
Duroc & 28 & 4 & 14.29 \\
Chester White & 81 & 6 & 7.4 \\
\hline
\end{tabular}

$B A X, B C L 2$-associated X protein.

Table 3. Incidence of heterozygous mutants among different breeds

\begin{tabular}{lccc}
\hline Breed & $\begin{array}{c}\text { Number of } \\
\text { samples }\end{array}$ & $\begin{array}{c}\text { Heterozygous } \\
\text { mutants }\end{array}$ & Incidence (\%) \\
\hline Pietrain & 98 & 32 & 32.65 \\
Landrace & 121 & 7 & 5.79 \\
Large White & 207 & 19 & 9.18 \\
Duroc & 28 & 8 & 28.57 \\
Chester White & 81 & 14 & 17.28 \\
\hline
\end{tabular}

mutation directly contributes to the development of hernia. Other SNP in the regulatory and coding region in the $B A X$ gene can also be studied.

There are no studies yet showing any breed correlations in the development of scrotal hernia. However, this study showed that the Pietrain breed showed highest incidence of the mutation, out of 98 Pietrain samples tested, 26 (26.5\%) were found to be homozygous mutants while 32 samples were heterozygous mutants. This was followed by Duroc with 4 homozygous mutants and 8 heterozygous mutants out of 28 (14.29\%), then followed by the Chester White, Large White, then Landrace (Tables 2 and 3 ).

According to Magee et al [19], scrotal hernia heritability was estimated to be 0.157 . Although various evidence points to the polygenic nature of scrotal hernia, there is still no definite evidence supporting it up to present. Moreover, environmental factors are also considered as contributors to the development of scrotal hernia [8]. At present, the only way to reduce the effect of this defect is for the breeders to eliminate boars which produce litter exhibiting high rate of scrotal herniation [13]. Still, this method does not consider the influence of sow. Thus, screening for the mutation in $B A X$ gene associated with scrotal hernia may help reduce the chances developing the defect as not only boars will be tested but also the sows that may be carrying the defect.

\section{IMPLICATIONS}

This study entailed the use of 538 randomly selected breeder swine in order to detect the presence of the polymorphism in $B A X$ gene associated with Scrotal Hernia in the commercial swine population. The data showed that $76.4 \%$ of the tested population were free of the mutation in the $B A X$ gene. The 
remaining $8.7 \%$ and $14.9 \%$ were homozygous mutants and heterozygous mutants, respectively. This indicates a high prevalence and frequency of the mutation in the tested population from the swine industry in the Philippines. Thus, this may be an indication of the high incidence of this defect in the swine populations in the country, showing the importance of conducting genetic screening methods to eliminate breeders that are carriers of the defect.

\section{AUTHOR CONTRIBUTIONS}

JG Manalysay and CN Mingala designed the experiment, analyzed and interpreted the data, and did the critical and final revision of the manuscript. While ND Antonio, RLR Apilado, JF Bambico did the acquisition of data and drafting of manuscript.

\section{CONFLICT OF INTEREST}

We certify that there is no conflict of interest with any financial organization regarding the material discussed in the manuscript.

\section{ACKNOWLEDGMENTS}

We thank Dr Arnel N Del Barrio, Philippine Carabao Center (PCC) Executive Director, for the support to finish the study. Thanks to the Department of Science and Technology-Philippine Council for Agriculture, Aquatic and Natural Resources Research and Development (DOST-PCAARRD) for the research grant under the Swine Genomics Project 2 and for monitoring the progress of this research. Also, special thanks to all the staff of the Animal Health Unit of PCC for their technical support.

\section{REFERENCES}

1.Swine Industry Performance Report as of June 2012 [Internet]. BAS (Bureau of Agricultural Statistics) [cited 2015 October 22]. Available from https://psa.gov.ph/content/swine-industry-performance-report-january-june-2012.

2.Vogt DW, Ellersieck MR. Heritability of susceptibility to scrotal herniation in swine. Am J Vet Res 1990;51:1501-3.

3.Gatphayak K, Charoensook R, Taesoongnern S, et al. Identification of porcine hernia inguinalis/scrotalis using single nucleotide polymorphism in INSL3 and Bax genes. In: Proceedings of the 2007 Tropentag. 2007 October 9-11: University of Kassel, Witzenhausen, Germany: Cuvillier Verlag Göttingen; 2007. 554 p.

4.Bates, RO. Hernias in growing swine. Mich State Univ Pork Q 2008;13:10.

5.Beck J, Bornemann-Kolatzki K, Knorr C, Taeubert H, Brenig B. Molecular characterization and exclusion of porcine GUSB as a candidate gene for congenital hernia inguinalis/scrotalis. BMC Vet Res 2006;2:14.

6.Du ZQ, Zhao X, Vukasinovic N, et al. Association and haplotype analyses of positional candidate genes in five genomic regions linked to scrotal hernia in commercial swine lines. PLoSONE 2009;4:e4837.

7.Zhao X. A candidate gene association study of cryptorchidism and scrotal hernia using canine and porcine models. [MS thesis] Ames, IA: Iowa State University; 2009.

8.Deeb N, Cleveland MA, Forni S, et al. Genome-wide association study for scrotal hernia in commercial swine populations. In: Proceedings of the 9th World Congress on Genetics Applied to Livestock Production. 2010 August 1-6: Congress Center Leipzig Messeallee 1, Leipzig, Germany: International Committee for World Congresses on Genetics Applied to Livestock Production and German Society for Animal Science; 2010. 575 p.

9.Grindflek E, Moe M, Taubert H, et al. Genome-wide linkage analysis of inguinal hernia in pigs using affected sib pairs. BMC Genet 2006;7:25.

10. Ding NS, Mao HR, Guo YM, et al. A genome-wide scan reveals candidate susceptibility loci for swine hernias in an intercross between White Duroc and Erhualian. J AnimSci 2009;87:246974.

11. Tanyel FC. Obliteration of processus vaginalis: aberrations in the regulatory mechanism result in an inguinal hernia, hydrocele or undescended testis. Turk J Pediatr 2004;46:18-27.

12. Osorio LM, De Santiago A, Aguilar-Santelises HM, Mellstedt K, Jondal M. CD6 ligation modulates the $\mathrm{Bcl}-2 / \mathrm{Bax}$ ratio and protects chronic lymphocytic leukemia B cells from apoptosis induced by anti-IgM. Blood 1997;89:2833-41.

13. Berge S. Three hereditary anomalies in swine. Hereditas 1941;27: 176-92.

14. Rasmussen HB [Internet]. Intechopen; c2012 [cited 2015 September 2]. Available from: http://www.intechopen.com/books/ gel-electrophoresis-principles-and-basics/restriction-fragmentlength-polymorphism-analysis-of-pcr-amplified-fragments-pcrrflp-and-related-te

15. Prezioso, V, Jahns, A, Eppendorf Scientific Inc. [Internet]. Drug Discovery Online; c2012 [cited 2015 October 10]. Available from http://www.drugdiscoveryonline.com/doc/using-gradient-pcrto-determine-the-optimum-a-0002

16. Vanags DM, Orrenius S, Aguilar-Santelises M. Alterations in Bcl-2/ Bax protein levels in platelets form part of an ionomycin-induced process that resembles apoptosis. Br J Haematol 1997;99:824-31.

17. Yang E, Korsmeyer SJ. Molecular thanatopsis: a discourse on the BCL2 family and cell death. Blood 1996;88:386-401.

18. Cory S, Adams JM. The Bcl2 family: regulators of the cellular lifeor-death switch. Nat Rev Cancer 2002;2:647-56.

19. Magee WT. Inheritance of scrotal hernia in swine. J Anim Sci 1951;10:516-22. 